\title{
Differences in ride-hailing adoption by older Californians among types of locations
}

\author{
Manish Shirgaokar (corresponding author) \\ University of Colorado Denver \\ manish.shirgaokar@ucdenver.edu
}

Asha Weinstein Agrawal

San José State University

asha.weinstein.agrawal@sjsu.edu

\section{Bonnie Dobbs}

Department of Family Medicine, University

of Alberta

bonnie.dobbs@ualberta.ca

\author{
Aditi Misra \\ University of Michigan Transportation \\ Research Institute \\ aditimis@umich.edu \\ Martin Wachs \\ University of California, Los Angeles \\ mwachs@ucla.edu
}

\begin{abstract}
Ride-hailing services such as Lyft and Uber can complement rides offered by family, friends, paid providers, and public transit. To learn why older adults might wish to use ride-hail, we conducted an online survey of 2,917 California respondents age 55 and older. Participants were asked whether they would value four features hypothesized to be benefits of ride-hailing. We specified binary logit models and used market segmentation to investigate whether there were location-based differences in the use of ride-hailing. Our analysis showed that women, city dwellers, persons with disabilities, and those who rely on others for rides were more open to ride-hailing. Women in suburbs or small town/ rural settings were more likely to ride-hail than their male counterparts for reasons of independence, fear of being lost while driving, or getting help with carrying bags. Urban women, in contrast, were less likely than their male counterparts to ride-hail for these reasons. High-income individuals in suburbs or small town/rural locations were more likely to ride-hail than low-income respondents, while high-income urban residents were less likely to ride-hail. Adoption of ride-hailing services and the reasons for doing so showed strong variability by location even among respondents with similar socio-demographic attributes.
\end{abstract}

Keywords: Gender, home location, older adults, ride-hailing, technology adoption

\section{Article history:}

Received: June 21, 2020

Received in revised form:

October 6, 2020

Accepted: October 29, 2020

Available online: March 9, 2021

\section{$1 \quad$ Introduction: Which older adults might step into a Lyft or Uber?}

Ride-hailing - the services provided by Transportation Network Companies such as Lyft and Uber-is a relatively new mode of travel that is growing in importance in many countries in the world, including the United States (Tirachini, 2019). Ride-hailing is widely available in metropolitan areas (Hughes $\&$ MacKenzie, 2016; Yu \& Peng, 2019). Although ride-hailing companies claim that their services are

Copyright 2021 Manish Shirgaokar, Aditi Misra, Asha Weinstein Agrawal, Martin Wachs \& Bonnie Dobbs http://dx.doi.org/10.5198/jtlu.2021.1827

ISSN: $1938-7849$ | Licensed under the Creative Commons Attribution - Noncommercial License 4.0

The Journal of Transport and Land Use is the official journal of the World Society for Transport and Land Use (WSTLUR) and is published and sponsored by the University of Minnesota Center for Transportation Studies. 
available across all of California (our geography of focus in this paper) including non-urban locations, availability can vary across environments (Brown, 2019a). Because ride-hailing typically requires use of the internet and credit cards, there is a clear association between use of this mode of transportation and travelers' ages. Direct experience with and peer opinions about ride-hailing services may also influence older adults' attitudes toward using ride-hailing. The next 10-year cohort (currently 55 to 64 years old) has more experience with app-based services and therefore may be more likely to use ride-hailing services than are those currently over age 64 . It seems possible that the use of ride-hailing will depend on the availability of other travel options including public transit and autonomous vehicles.

Recent scholarship shows that most ride-hailing users are young and educated individuals (Alemi, Circella, Handy, \& Mokhtarian, 2018; Conway, Salon, \& King, 2018; Grahn, Harper, Hendrickson, Qian, \& Matthews, 2019; Vivoda, Harmon, Babulal, \& Zikmund-Fisher, 2018). There is little research, however, on whether older adults are willing to adopt ride-hailing services. The limited research that is available indicates that few seniors use ride-hail to meet their mobility needs (Vivoda et al., 2018). Researchers have written about the inability of seniors to access ride-hailing as a viable travel mode due to their unfamiliarity with e-tools (Payyanadan \& Lee, 2018; Shirgaokar, 2018; Vivoda et al., 2018). Leistner and Steiner (2017) present a rare case study of a program to supply rides to seniors via a ridehailing app in lieu of transit in Gainesville, FL. That study found that older women were more likely to enroll in the program, were more open to using the service, and continued to use it longer than their older male counterparts.

The literature indicates a gap in understanding the influence of home location on the motivations and attitudes of older adults toward ride-hailing. Location is an especially pertinent factor given that most older adults will "age in place" (Chen, Bouferguene, Shirgaokar, \& Al-Hussein, 2020; Coughlin, 2009). Following this view, the objective of this paper is to understand if reasons to accept ride-hailing services are influenced by socio-demographic differences among Californians aged 55 and older, particularly as a function of the location type where people live. To address this objective, we explore whether the factors that might encourage ride-hailing among Californians aged 55 and older would depend on the type of community where respondents lived: urban, suburban, small town, or rural areas. We explore possible latent demand for ride-hailing services across these location types in California. We also investigate whether attitudes associated with respondents from these locations differ by gender.

We conducted an online survey of 2,917 respondents 55 and older who live in California. Participants were asked about various aspects of ride-hailing acceptance, including features that may facilitate the use of ride-hailing. We specified binary logit models and used market segmentation (Koppelman \& Bhat, 2006) to understand whether there are location type differences in use of ride-hailing. Our modeling segments the sample by stated home location in order to capture home location effects.

The dependent variables are four specific reasons that might incentivize individuals aged 55 and older to adopt ride-hailing (Table 1). We tested four hypotheses about adults who are 55 and older:

- Hypothesis 1 - Socio-Demographics: Reasons to adopt ride-hailing are distinctly different across socio-economic segments (gender, income, etc.)

- Hypothesis 2 - Independence: Those who are dependent on others for rides are more likely to find one or more of the reasons important to accept ride-hailing.

- Hypothesis 3-Health/Ability: Those who identify as a person with disability and/or report presence of physical health conditions are likely to find one or more of the reasons important to ride-hail.

- Hypothesis 4 - Location/Community Type: The results of the preceding three hypotheses are not equal across different location types (urban, suburban, and small town/rural). 


\section{Older adults, their travel behaviors, and ride-hailing: A literature review}

\subsection{A population aging in place and impacts of diminished travel}

The population of the United States is aging. The US Census Bureau projects that the number of people over age 65 will increase from 56 million in 2020 to 81 million by 2040 (US Census Bureau, 2018). In addition to this growth in absolute numbers, the Census Bureau predicts that older adults will become a larger fraction of the population, growing from $17 \%$ of the total population in 2020 to $22 \%$ of the population in 2040 (US Census Bureau, 2018).

Research indicates that individuals 65 and older are more likely to age in place than move late in life (Coughlin, 2009), with $88 \%$ of senior respondents in a 2010 survey indicating that they preferred to age in place (Keenan 2010, p. 4 and 11). A majority of respondents in that study said that it was extremely or very important for them to be in a community that is near family and friends $(71 \%)$, close to where they want to go (70\%), and near social organizations (57\%). Other studies indicate that the senior population is growing faster in suburbs and rural locations than in city centers (Frey, 2011; Parker et al., 2018; Rosenbloom, 2012). In addition, seniors who do not live in city centers are particularly at risk of being transportation deficient (Kim, 2011a; Shirgaokar, Dobbs, Anderson, \& Hussey, 2020).

Factors such as cognitive function, physical limitations, financial barriers, and social norms are all associated with diminishing travel among seniors (Chihuri et al., 2016). Notably, driving cessation is associated with an overall decrease in health and wellbeing, diminished social life, and a doubling of depression rates (Chihuri et al., 2016). Analyses using American Association of Retired Persons (AARP) data found that a smaller social network, lower socio-economic status, lack of transportation options, and living in an unwalkable location are all connected to a lower quality of life among seniors (Kim \& Ulfarsson, 2013; Kim, 2011b). The literature also suggests that the health impacts of aging affect travel and, in turn, lead to diminished life satisfaction (Enam, Konduri, Eluru, \& Ravulaparthy, 2017; Li \& Tilahun, 2017). By contrast, an active lifestyle and traveling to socialize can improve quality of life in older adults (Chen et al., 2020; Ravulaparthy, Konduri, \& Goulias, 2016).

\subsection{Seniors' travel behaviors}

A literature review by Haustein and Siren (2015) concluded that seniors could be segmented by travel patterns into four groups: (a) affluent and active car users, (b) car-dependent users with limited activity, (c) multimodal and active users, or (d) users dependent on transit and other travel means. Older adults further vary in terms of their travel patterns across age cohorts. Aging occurs over decades resulting in significant differences between those entering the older adult category and those who are much older (Rosenbloom \& Herbel, 2009). For example, in the United States, driver status decreases with age, especially for adults 85 and older and for non-white Americans (Rosenbloom, 2012). Mode choice is heavily reliant on access to private automobiles, but trips as car passengers, compared to being the driver, increase rapidly with age (Rosenbloom, 2012).

Driving Automobiles and Driving Cessation: Seniors drive less frequently and fewer miles as they age, yet on average older adults rely on driving as long as they are able to do so (Rosenbloom, 2012). Siren and Haustein (2013) also found that baby-boomer seniors (i.e., those born between 1946 and 1964) are more car-dependent than other groups, and that men drive more than women do within this demographic. However, the later in life that seniors drive, the more likely they are to be in an injurious or fatal crash due to changes in functional abilities. These changes are due to the presence of one or more medical conditions and/or the medications used to treat those conditions, rather than age alone (Diller 
et al., 1999; Vaa, 2003).

Non-driving seniors and individuals with lower income have the smallest activity area compared to those who drive (Kim \& Ulfarsson, 2015) in that driving extends accessibility to various destinations (Figueroa, Nielsen, \& Siren, 2014; Hess, Norton, Park, \& Street, 2016). In addition, driving is associated with increased life satisfaction for many seniors (Li \& Tilahun, 2017). Many factors are associated with seniors' driving needs such as living in a location for more years (Hess et al., 2016) or living in suburbs or exurbs (Kim \& Ulfarsson, 2015). In an AARP survey, Kim (2011b) found that seniors were more likely to get rides from someone, rather than relying on transit and walking, once they stop driving. Foley, Heimovitz, Guralnik, and Brock (2002) also found that older men and women outlive their driving age by six and ten years respectively.

Senior Women: It is important to understand gender-based variation in demand for various travel modes (Shirgaokar, 2018; Su \& Bell, 2012). In general, women live longer than men, although this gap is narrowing as the life expectance for men in the United States has gradually increased in the last four decades (Medina, Sabo, \& Vespa, 2020). The gender gap in driver's license also is declining for US adults 65 and older; today's older women are more likely to hold a license than were older women in previous generations (Federal Highway Administration, 2018). Nevertheless, older women generally drive less than their same-aged male counterparts. As such, older women are more dependent than older men on others to meet their transportation needs (Foley et al., 2002; Rosenbloom, 2011; Rosenbloom \& Winsten-Bartlett, 2002). A lack of travel options especially affects older minority women (Kim, 2011a). Senior baby-boomer women, who have been dependent on the automobile their entire adult lives, are more likely to face unmet transportation needs and dependence on others as they age compared to same-aged males (Rosenbloom \& Herbel, 2009).

\subsection{Ride-hailing}

Most research on ride-hailing has focused on millennials, generation Xers, and regular travelers. Methodologically, online surveys (Alemi, Circella, Mokhtarian, \& Handy, 2019; Middleton \& Zhao, 2019), spatio-temporal data on use of ride-hailing (Brown, 2019a; Erhardt et al., 2019), and intercept surveys (Gehrke, Felix, \& Reardon, 2019; Henao \& Marshall, 2018) have been utilized to unearth dimensions of ride-hailing usage in cities. Tirachini (2019) provides an in-depth literature review of ride-hailing scholarship from developed and developing countries.

Whom does ride-hailing serve: The literature suggests that the average ride-hailing user tends to be young, employed (often with a flexible schedule), educated, male, and urban-dwelling (Alemi et al., 2018; Conway et al., 2018; Grahn et al., 2019; Vivoda et al., 2018; Yu \& Peng, 2019). However, ridehailing is used infrequently by all users, though more use is seen among those dwelling in households with fewer vehicles than workers (Brown, 2019a; Grahn et al., 2019; Sikder, 2019). Some researchers have found that ride-hailing is inequitable. Minorities face more challenges in hailing and successfully completing rides (Conway et al., 2018). Sikder (2019) further finds that African Americans and households that include older adults or young children are less likely to ride-hail. Hughes and MacKenzie (2016) suggest, however, that supply efficiency of ride-hailing is correlated with density of population and time of day rather than the socio-economic characteristics of an area. Brown (2019b) finds that ride-hailing is more reliable and less discriminatory than taxi service for minorities and in low-income locations in Los Angeles, California. Middleton and Zhao (2019) examine shared trip preferences with respect to ride-hailing services and find that males, women traveling with children, and those living in areas with high average income and conservative political leanings are likely to hold negative attitudes 
toward fellow riders of a different race. Conway et al. (2018), using the National Household Travel Survey, find that there are differences across users and by location. Specifically, denser locations tend to have higher use of ride-hailing (Alemi et al., 2019; Conway et al., 2018; Grahn et al., 2019). Yet, in the Los Angeles area, Brown (2019a) finds that ride-hailing is ubiquitous, being supplied and consumed in low-density areas as well as in urban centers.

\section{Data collection and sample characteristics}

Seniors are a large and growing segment of the population in California, which is the geography of focus for this research. We defined seniors as individuals 65 years of age or older, but we also considered people between 55 to 64 years of age since they will be seniors in the very near future. Projections suggest that California's population over age 65 will increase from 6.4 million in 2020 to a little over 11 million in 2040 (California Dept. of Finance, 2020). Many of these future seniors are likely to be comfortable with technology-based travel services such as ride-hailing given their familiarity with e-tools today.

We collected data from the respondents through an online survey (for complete methodological details, see Agrawal, Shirgaokar, Misra, Wachs, \& Dobbs, 2020). Online surveys are a method increasingly used by researchers (Alemi et al., 2019; Middleton \& Zhao, 2019). Our calculations based on American Community Survey (ACS) 5-year housing and person Public Use Microdata Sample (PUMS) data show that $86 \%$ percent of California's population over the age of 55 has access to the internet and $73 \%$ has access to a smartphone. Given the high percentage of older Californians using the internet, online surveys are a reasonable method for inexpensively capturing information from a large segment of the population. Still, it is important to take note that online samples under-represent people with certain socio-demographic characteristics, including those who are over 75 , have low income, have less formal education, and do not have high-speed internet access at home. Their exclusion is a limitation of on-line surveys.

To ensure a sample that closely represented California adults 55 and older in terms of basic sociodemographic characteristics, we used quota sampling. We requested that the data vendor provide a sample that represented California adults 55 and older in terms of 2017 ACS 5-year estimates for gender, race and ethnicity, employment status, annual household income, and age. The data were also sampled by Zip Code so that the sample would represent various types of communities found across California, including, urban centers, suburbs, and small town/rural areas.

We designed the survey instrument to elicit responses regarding ride-hailing service availability and use patterns under a variety of trip scenarios. Moreover, we collected information about respondents' comfort using technology (e.g., using apps on smartphones) and online financial tools (e.g., online credit card use). We also asked questions about travel modes used in the preceding month; socio-economic characteristics of age, gender, race, ethnicity, employment status, and household income; and disability and health status.

The survey was administered from June 19 to September 9, 2019. Respondents completed surveys in an average of 11 minutes ( 8 minutes median). We received completed records for 2,917 respondents. The unweighted sample was $55 \%$ female. In terms of race and ethnicity, the unweighted sample was 16\% Hispanic/Latino, 59\% white, 16\% Asian-American, and 8\% African-American. As for education, $53 \%$ of respondents were college graduates, $34 \%$ had some college education, and $13 \%$ had completed high school or a Graduate Equivalency Diploma (GED). Most of the sample (61\%) was not working by choice, $35 \%$ worked for pay, and $4 \%$ were unemployed but looking for work. The median as well as average age of the sample was 66 years with a standard deviation of 7.8 years. Forty-five percent $(45 \%)$ of the sample were in the 55-64 age category, 38\% were in the 65-74 age bracket, and the remaining 
$17 \%$ were in the $75+$ age group. The sample's median annual household income was $\$ 87,500$ (Mean $=$ $\$ 100,300 ; \mathrm{SD}=\$ 73,800)$.

\section{$4 \quad$ Analytical approach}

The underlying theory of market segmentation is that the types of people who consume different services are fundamentally different from each other (Ben-Akiva et al., 2002; Koppelman \& Bhat, 2006). Differences can arise for many reasons, including socio-demographic factors (e.g., different age cohorts) or latent factors (e.g., high versus low confidence using smartphone apps). Since researchers indicate that there are differences in ride-hailing preferences by home location (Brown, 2019a; Yu \& Peng, 2019), we contend that differences in adoption of such services can also arise from where respondents live. Therefore, we segmented the sample by the type of self-reported home location and used a market segmentation approach (Koppelman \& Bhat, 2006, Chapter 6) to test differences in reasons for adopting ride-hailing across three types of markets: urban, suburban, and small town/rural areas.

The dependent variables were constructed from survey questions that asked respondents to consider if each of four statements about ride-hailing described a reason that might encourage them to accept such services (Table 1). Specifically, respondents were directed to "think about all the trips you might be able to make using ride-hailing. Do these statements describe reasons you might want to use ridehailing, given your current lifestyle?" Respondents could answer "yes," "maybe," or "no" to these four statements. These prompts were developed by authors based on a review of the literature and subject area expertise (e.g., Shirgaokar, 2018). Because each of the four reasons tested was presented separately to the respondents, each statement is treated as a distinct binary outcome variable. Each model examines whether one of the independent variables (Table 2) significantly shift the likelihood of moving from a "no" to a "yes" for ride-hailing adoption.

Table 1. Distribution of the outcome variables: Reasons to adopt ride-hailing

\begin{tabular}{|l|cc|cc|cc|cc|}
\hline & \multicolumn{2}{|c|}{$\begin{array}{c}\text { I can go out without } \\
\text { having to ask family/ } \\
\text { friends for rides }\end{array}$} & \multicolumn{2}{|c|}{$\begin{array}{c}\text { I can go out at night } \\
\text { without having to } \\
\text { drive myself }\end{array}$} & \multicolumn{2}{|c|}{$\begin{array}{c}\text { I don't have to worry } \\
\text { about getting lost } \\
\text { driving myself }\end{array}$} & $\begin{array}{c}\text { I have help carrying } \\
\text { heavy bags to my } \\
\text { door }\end{array}$ \\
\hline & Obs. & $\%$ & Obs. & $\%$ & Obs. & $\%$ & Obs. & $\%$ \\
\hline Yes/Maybe = 1 & 1,783 & $61 \%$ & 1,905 & $65 \%$ & 1,697 & $58 \%$ & 1,506 & $52 \%$ \\
No = 0 & 1,119 & $38 \%$ & 995 & $34 \%$ & 1,202 & $41 \%$ & 1,384 & $47 \%$ \\
Missing & 15 & $1 \%$ & 17 & $1 \%$ & 18 & $1 \%$ & 27 & $1 \%$ \\
\hline Total & 2,917 & $100 \%$ & 2,917 & $100 \%$ & 2,917 & $100 \%$ & 2,917 & $100 \%$ \\
\hline
\end{tabular}

We tested whether the answer to each outcome variable depended on the respondent's home location. Responses to the question "How would you describe the area you live in?" were used as an explanatory variable in the base models (Table 3) and later for exogenous segmentation of the data (Table 4, Table 5, Table 6). The self-reported home location categories were urban, suburban, small town, and rural. However, the small town and rural categories were combined together because of the lower response rates in both these groups. Separate models for each geographical location were specified so that the larger groups did not mask preferences of the smaller group. Since home location is self-reported, there may be bias in how respondents self-identify where they live. Nevertheless, formal definitions of location type, e.g., urban versus suburban, can be contested especially in boundary locations. Letting respondents report how they view their home location may add more insights given our hypotheses. In 
future work, specific addresses linked to respondents would be ideal.

Table 2 presents the summary of variables used in this analysis across the different self-reported home locations. Explanatory variables in the models include factors for travel behavior (commuting, car driving, and getting rides) and health (disability and physical ability to carry out everyday tasks). Sociodemographic variables including gender, age, race, ethnicity, education, and household income were also considered as explanatory variables.

Table 2. Summary statistics for independent variables across different home locations

\begin{tabular}{|c|c|c|c|c|c|c|}
\hline \multicolumn{2}{|c|}{ Independent variables } & Urban & Suburb & Small Town & Rural & Full Sample \\
\hline \multicolumn{7}{|c|}{ Commute days per week } \\
\hline & Mean & 3.8 & 3.9 & 3.9 & 3.8 & 3.9 \\
\hline & $\mathrm{SD}$ & 1.5 & 1.5 & 1.5 & 1.5 & 1.5 \\
\hline \multicolumn{7}{|c|}{ Drove a car last week } \\
\hline \multirow[t]{2}{*}{ Yes } & Row $\%$ & $26 \%$ & $58 \%$ & $10 \%$ & $6 \%$ & $100 \%$ \\
\hline & $\mathrm{Col} \%$ & $84 \%$ & $93 \%$ & $87 \%$ & $87 \%$ & $89 \%$ \\
\hline \multirow[t]{2}{*}{ No } & Row\% & $41 \%$ & $39 \%$ & $12 \%$ & $8 \%$ & $100 \%$ \\
\hline & $\mathrm{Col} \%$ & $16 \%$ & $7 \%$ & $13 \%$ & $13 \%$ & $11 \%$ \\
\hline \multicolumn{2}{|l|}{ Obs. } & 799 & 1,609 & 300 & 188 & 2,896 \\
\hline \multicolumn{7}{|c|}{$\begin{array}{l}\text { Got a ride from Family/Friends/ } \\
\text { Neighbors/Caregivers }\end{array}$} \\
\hline \multirow[t]{2}{*}{ Last 7 days } & Row\% & $27 \%$ & $56 \%$ & $11 \%$ & $7 \%$ & $100 \%$ \\
\hline & $\mathrm{Col} \%$ & $47 \%$ & $49 \%$ & $51 \%$ & $50 \%$ & $48 \%$ \\
\hline \multirow[t]{2}{*}{ Last month } & Row $\%$ & $27 \%$ & $57 \%$ & $10 \%$ & $6 \%$ & $100 \%$ \\
\hline & $\mathrm{Col} \%$ & $26 \%$ & $27 \%$ & $25 \%$ & $24 \%$ & $26 \%$ \\
\hline \multirow[t]{2}{*}{ Never } & Row\% & $30 \%$ & $54 \%$ & $10 \%$ & $7 \%$ & $100 \%$ \\
\hline & $\mathrm{Col} \%$ & $27 \%$ & $24 \%$ & $24 \%$ & $26 \%$ & $25 \%$ \\
\hline \multicolumn{2}{|l|}{ Obs. } & 795 & 1,596 & 293 & 186 & 2,876 \\
\hline \multicolumn{7}{|c|}{ Disability status } \\
\hline \multirow[t]{2}{*}{ Yes } & Row $\%$ & $31 \%$ & $46 \%$ & $16 \%$ & $6 \%$ & $100 \%$ \\
\hline & $\mathrm{Col} \%$ & $13 \%$ & $9 \%$ & $17 \%$ & $11 \%$ & $11 \%$ \\
\hline \multirow[t]{2}{*}{ No } & Row\% & $27 \%$ & $57 \%$ & $10 \%$ & $7 \%$ & $100 \%$ \\
\hline & $\mathrm{Col} \%$ & $87 \%$ & $91 \%$ & $83 \%$ & $89 \%$ & $89 \%$ \\
\hline \multicolumn{2}{|c|}{ Obs. } & 806 & 1,605 & 298 & 189 & 2,898 \\
\hline \multicolumn{7}{|c|}{$\begin{array}{l}\text { Has physical health concerns that } \\
\text { interfere with ability to carry out daily } \\
\text { activities }\end{array}$} \\
\hline \multirow[t]{2}{*}{ Yes } & Row\% & $32 \%$ & $44 \%$ & $16 \%$ & $8 \%$ & $100 \%$ \\
\hline & $\mathrm{Col} \%$ & $8 \%$ & $6 \%$ & $11 \%$ & $9 \%$ & $7 \%$ \\
\hline \multirow[t]{2}{*}{ No } & Row $\%$ & $27 \%$ & $56 \%$ & $10 \%$ & $6 \%$ & $100 \%$ \\
\hline & $\mathrm{Col} \%$ & $92 \%$ & $94 \%$ & $89 \%$ & $91 \%$ & $93 \%$ \\
\hline \multicolumn{2}{|l|}{ Obs. } & 805 & 1,608 & 299 & 190 & 2,902 \\
\hline \multicolumn{7}{|l|}{ Gender } \\
\hline \multirow[t]{2}{*}{ Female } & Row $\%$ & $29 \%$ & $53 \%$ & $11 \%$ & $7 \%$ & $100 \%$ \\
\hline & $\mathrm{Col} \%$ & $57 \%$ & $53 \%$ & $58 \%$ & $63 \%$ & $55 \%$ \\
\hline \multirow[t]{2}{*}{ Male } & Row\% & $27 \%$ & $58 \%$ & $10 \%$ & $5 \%$ & $100 \%$ \\
\hline & $\mathrm{Col} \%$ & $43 \%$ & $47 \%$ & $42 \%$ & $37 \%$ & $45 \%$ \\
\hline \multicolumn{2}{|l|}{ Obs. } & 806 & 1,604 & 299 & 187 & 2,896 \\
\hline
\end{tabular}




\begin{tabular}{|c|c|c|c|c|c|c|}
\hline \multicolumn{2}{|c|}{ Independent variables } & Urban & Suburb & Small Town & Rural & Full Sample \\
\hline \multicolumn{7}{|c|}{ Age } \\
\hline \multirow{2}{*}{$\begin{array}{l}65+\text { years } \\
\text { (older adult) }\end{array}$} & Row\% & $26 \%$ & $57 \%$ & $10 \%$ & $6 \%$ & $100 \%$ \\
\hline & $\mathrm{Col} \%$ & $52 \%$ & $57 \%$ & $56 \%$ & $53 \%$ & $55 \%$ \\
\hline \multirow[t]{2}{*}{ 55-64 years } & Row\% & $30 \%$ & $53 \%$ & $10 \%$ & $7 \%$ & $100 \%$ \\
\hline & $\mathrm{Col} \%$ & $48 \%$ & $43 \%$ & $44 \%$ & $47 \%$ & $45 \%$ \\
\hline Obs. & & 807 & 1,612 & 301 & 190 & 2,910 \\
\hline \multicolumn{7}{|l|}{ Race } \\
\hline \multirow[t]{2}{*}{ White } & Row\% & $24 \%$ & $58 \%$ & $10 \%$ & $7 \%$ & $100 \%$ \\
\hline & $\mathrm{Col} \%$ & $51 \%$ & $62 \%$ & $58 \%$ & $64 \%$ & $59 \%$ \\
\hline \multirow[t]{2}{*}{ Other race/s } & Row\% & $33 \%$ & $51 \%$ & $10 \%$ & $6 \%$ & $100 \%$ \\
\hline & $\mathrm{Col} \%$ & $49 \%$ & $38 \%$ & $42 \%$ & $36 \%$ & $41 \%$ \\
\hline Obs. & & 807 & 1,612 & 301 & 190 & 2,910 \\
\hline \multicolumn{7}{|l|}{ Ethnicity } \\
\hline \multirow[t]{2}{*}{ Hispanic } & Row\% & $28 \%$ & $51 \%$ & $12 \%$ & $9 \%$ & $100 \%$ \\
\hline & $\mathrm{Col} \%$ & $16 \%$ & $15 \%$ & $18 \%$ & $21 \%$ & $16 \%$ \\
\hline \multirow[t]{2}{*}{ Non-Hispanic } & Row\% & $28 \%$ & $56 \%$ & $10 \%$ & $6 \%$ & $100 \%$ \\
\hline & $\mathrm{Col} \%$ & $84 \%$ & $85 \%$ & $82 \%$ & $79 \%$ & $84 \%$ \\
\hline \multicolumn{2}{|c|}{ Obs. } & 807 & 1,612 & 301 & 190 & 2,910 \\
\hline \multicolumn{7}{|c|}{$\begin{array}{l}\text { College educated (4-year college degree } \\
\text { or post-graduate degree) }\end{array}$} \\
\hline \multirow[t]{2}{*}{ Yes } & Row\% & $27 \%$ & $58 \%$ & $10 \%$ & $5 \%$ & $100 \%$ \\
\hline & $\mathrm{Col} \%$ & $52 \%$ & $56 \%$ & $50 \%$ & $43 \%$ & $53 \%$ \\
\hline \multirow[t]{2}{*}{ No } & Row\% & $29 \%$ & $52 \%$ & $11 \%$ & $8 \%$ & $100 \%$ \\
\hline & $\mathrm{Col} \%$ & $48 \%$ & $44 \%$ & $50 \%$ & $57 \%$ & $47 \%$ \\
\hline \multicolumn{2}{|l|}{ Obs. } & 807 & 1,607 & 301 & 189 & 2,904 \\
\hline \multicolumn{7}{|c|}{$\begin{array}{l}\text { Pre-tax annual household income in } \\
2018\end{array}$} \\
\hline & Mean & 90,753 & 110,293 & 85,083 & 81,763 & 100,324 \\
\hline & SD & 73,357 & 73,746 & 68,451 & 71,071 & 73,768 \\
\hline
\end{tabular}

We specified a set of logistic regression models for the four outcome variables (Table 3) which examined reasons for adopting ride-hailing. We estimated ordinal logistic models as well as binary logistic models, and found fit statistics to be similar for both types. The binary logistic models are presented here because they are simpler and easier to interpret. We anticipated that getting rides from family/friends/neighbors and being driven rather than driving might be multi-collinear and be endogenous with some of the outcome variables, particularly for model \#1 (Table 3). Pairwise measures of association were used to ascertain whether the explanatory variables were correlated, and later a variation inflation factor (VIF) test was run to check for multicollinearity. The association between variables was found to be weak with a maximum association measure of 0.23 . The post-estimation check for VIF was much lower than five (5) across all variables. Parameter estimates and fit statistics for these base models are presented in Table 3. 


\section{$5 \quad$ Discussion of base binary logit models}

For each of the four dependent variables, we estimated standard binary logit models that have the same set of independent controls. At this stage, the full dataset was used, not segmenting by type of home location. These first models are numbered \#1 through \#4 (Table 3). Five variables were significantly correlated with valuing ride-hailing across all or most of the models. Three variables were significant across all four models, and in the same direction: being female, having obtained a ride in the last week, and having obtained a ride in the last month were associated with higher odds of valuing ride-hailing for all the reasons presented. Two other variables were significant for three of the models (only insignificant in model \#2). Having lower income and living in an urban location increased the odds that a respondent thought the stated reasons would nudge her or him into ride-hailing.

Table 3. Results of the four base binary logit models

\begin{tabular}{|c|c|c|c|c|c|c|c|c|}
\hline & \multicolumn{2}{|c|}{$\begin{array}{l}\text { I can go out without } \\
\text { having to ask family/ } \\
\text { friends for rides } \\
\text { (\#1) }\end{array}$} & \multicolumn{2}{|c|}{$\begin{array}{l}\text { I can go out at night } \\
\text { without having to } \\
\text { drive myself } \\
(\# 2)\end{array}$} & \multicolumn{2}{|c|}{$\begin{array}{l}\text { I don't have to worry } \\
\text { about getting lost } \\
\text { driving myself } \\
(\# 3)\end{array}$} & \multicolumn{2}{|c|}{$\begin{array}{l}\text { I have help carrying } \\
\text { heavy bags to my } \\
\text { door } \\
(\# 4)\end{array}$} \\
\hline & Coef. & Sig. & Coef. & Sig. & Coef. & Sig. & Coef. & Sig. \\
\hline $\begin{array}{l}\text { Number of days com- } \\
\text { muting per week }\end{array}$ & 0.08 & 0.09 & 0.02 & 0.70 & 0.01 & 0.91 & 0.05 & 0.29 \\
\hline Drove a car last week & -0.35 & 0.18 & -0.18 & 0.50 & -0.24 & 0.34 & -0.44 & $\mathbf{0 . 0 7}$ \\
\hline Got a ride last week & 0.58 & 0.00 & 0.70 & 0.00 & 0.58 & 0.00 & 0.44 & 0.02 \\
\hline Got a ride last month & 0.48 & 0.00 & 0.68 & 0.00 & 0.56 & 0.00 & 0.46 & 0.01 \\
\hline Has a disability & 0.54 & 0.14 & 0.46 & 0.23 & 0.55 & 0.12 & 0.99 & 0.01 \\
\hline $\begin{array}{l}\text { Has physical health } \\
\text { concerns that interfere } \\
\text { with ability to carry out } \\
\text { daily activities }\end{array}$ & 0.68 & 0.13 & 0.70 & 0.14 & 0.44 & 0.29 & 1.04 & 0.02 \\
\hline Female (ref. male) & 0.32 & 0.02 & 0.39 & 0.01 & 0.38 & 0.01 & 0.75 & 0.00 \\
\hline $\begin{array}{l}\text { Older Adult (ref. 55-64 } \\
\text { years) }\end{array}$ & -0.10 & 0.53 & -0.27 & 0.09 & -0.22 & 0.15 & -0.01 & 0.97 \\
\hline White (ref. other race/s) & -0.05 & 0.75 & 0.04 & 0.78 & -0.07 & 0.62 & 0.01 & 0.95 \\
\hline Hispanic & 0.26 & 0.18 & 0.40 & 0.05 & 0.24 & 0.20 & -0.23 & 0.21 \\
\hline Has a college degree & -0.10 & 0.53 & -0.10 & 0.55 & 0.03 & 0.87 & -0.20 & 0.20 \\
\hline $\begin{array}{l}\text { Pre-tax annual house- } \\
\text { hold income in } 2018 \text { (\$ } \\
10,000)\end{array}$ & -0.02 & 0.03 & 0.00 & 0.70 & -0.02 & 0.03 & -0.03 & 0.01 \\
\hline Urban & 0.46 & 0.05 & 0.33 & 0.18 & 0.41 & 0.08 & 0.54 & 0.02 \\
\hline Suburban & 0.09 & 0.68 & -0.01 & 0.95 & 0.08 & 0.71 & 0.23 & 0.29 \\
\hline (Intercept) & 0.16 & 0.70 & 0.17 & 0.68 & 0.21 & 0.61 & -0.33 & 0.41 \\
\hline \multicolumn{9}{|l|}{ Model Statistics } \\
\hline Obs. & 987 & & 990 & & 990 & & 983 & \\
\hline McFadden's $\rho 2$ & 0.68 & & 0.69 & & 0.68 & & 0.68 & \\
\hline AIC & 1255.63 & & 1202.10 & & 1281.90 & & 1287.00 & \\
\hline LL(MS) & -1934.68 & & -1864.91 & & -1966.70 & & -2000.62 & \\
\hline $\operatorname{LL}(\rho)$ & -613.81 & & -586.03 & & -625.96 & & -628.52 & \\
\hline
\end{tabular}

Note: (1) Binary logit models presented; (2) Bolded values are significant at 90\% 
A number of variables proved insignificant in all the models or were significant in only one of the models. These variables were: number of days/week commuting, having driven a car in the previous week, having a disability or physical health concerns, being 65 or older, being White (as opposed to all other races), being Hispanic, having a college degree, and living in a suburban community.

\section{$6 \quad$ Market segmentation models}

\subsection{The approach to market segmentation}

Because the self-reported home location was a significant explanatory variable for three of the outcome variable statements (Table 3), we ran segmented models for the location types and then measured whether the segmented models fit the data better than a pooled model. The purpose of the locational segmentation was to determine whether any of the explanatory variables was significantly different across location type and whether that difference was masked in the pooled model. Pooled models are particularly likely to mask variations among subgroups when there is high representation for some groups (here, urban and suburban) and low representation for others (here, small town and rural). The market segmentation analyses required three separate steps:

1. Running pooled models for the entire dataset to find the best specifications for the pooled model for each outcome variable.

2. Running separate binary logistic models for urban, suburban, and small town/rural subsets of the data to find the best specifications.

3. Testing variables that are significant in one of the segmented models but not in the pooled model to determine whether the coefficient estimates were significantly different (tested by t-tests). Each variable found to be significant was added as an interaction term in the final pooled model. For example, if being female was found to be significant in the urban model but not in the suburban model or the pooled model, then a new pooled model was created with an interaction term "urban $\times$ female." If that term was found to be significant in the pooled model only, then we concluded that the variable was significant for that group. We repeated this process for each variable, adding significant variables to the model sequentially and removing insignificant ones.

The final segmented models for urban, suburban, and small town/rural respondents, plus the pooled model, are presented in Table 4 (models \#5 through \#9), Table 5 (models \#10 through \#14), and Table 6 (models \#15 through \#19). The t-statistic for difference in coefficients between segments is calculated as below:

$$
t=\frac{\widehat{\beta}_{1}-\widehat{\beta}_{2}}{\sqrt{\operatorname{var}\left(\widehat{\beta}_{1}\right)+\operatorname{var}\left(\widehat{\beta}_{2}\right)}}
$$

To test whether the models were significantly different, a $\chi 2$ test of significance between the final pooled model and the segmented models was performed. As noted in Koppelman and Bhat (2006), the difference between the likelihood of the pooled model and the segmented models follows $\chi 2$ distribution. Mathematically,

$\left(-2 \times[\operatorname{LL}(\right.$ final pooled model)-LL(segment 1)-LL(segment 2) $]) \sim \chi^{2}{ }_{\mathrm{d}}$, 
where the degrees of freedom (df) is calculated as $\mathrm{K}_{1}+\mathrm{K}_{2}-\mathrm{K}$ where $\mathrm{K}$ is the number of coefficients in the pooled model and $\mathrm{K}_{\mathrm{s}}$ is the number of coefficients in the $\mathrm{s}^{\text {th }}$ market segment model, $s=1,2, . . \mathrm{n}$ (Koppelman \& Bhat, 2006). If the difference is significant at the desired level of confidence, the null hypothesis that the pooled model is same as the segmented model is rejected.

\subsection{Pooled and segmented modeling}

Table 4, Table 5, and Table 6 show the initial pooled, segmented, and the final pooled models. Being female is significant with a positive coefficient in the initial pooled $(\# 5, \# 10, \# 15)$ models and in the segmented suburb (\#7, \#12,\#17) and small town/rural (\#8,\#13,\#18) models. Receiving a ride from family, friends/neighbors, or caregivers is significant with a positive coefficient in the initial pooled ( $\# 5$, $\# 10, \# 15)$ models and in many of the segmented (\#6, \#8, \#11, \#12, \#17, \#18) models. However, annual household income is significant (but with a negative coefficient) across all initial pooled (\#5, \#10, \#15) models and most segmented (\#6, \#7, \#11, \#12, \#16) models.

From t-tests, for the outcome variable "I can go out without having to ask family/friends for rides," the coefficient of being female is significantly different between the initial pooled (\#5) model and urban segmented (\#6) model. Similarly, the coefficient of being female is significantly different between the pooled (\#5) model and the small town/rural segmented (\#8) model as is the coefficient of annual household income. Hence, we added three interaction terms in the final pooled (\#9) model, namely, (urban $\times$ female), (small town/rural $\times$ female), (small town/rural $\times$ Pre-tax annual household Income in 2018). Since all the interaction terms were found to be significant in the final pooled model (\#9), they were retained. 
Table 4. Non-reliance on family and friends for a ride: A reason for adopting ride-hailing?

\begin{tabular}{|c|c|c|c|c|c|c|c|c|c|c|}
\hline & \multicolumn{2}{|c|}{$\begin{array}{l}\text { Initial Pooled } \\
\text { Model } \\
(\# 5)\end{array}$} & \multicolumn{2}{|c|}{$\begin{array}{l}\text { Urban-only } \\
\text { Model } \\
(\# 6)\end{array}$} & \multicolumn{2}{|c|}{$\begin{array}{c}\text { Suburb-only } \\
\text { Model } \\
(\# 7)\end{array}$} & \multicolumn{2}{|c|}{$\begin{array}{l}\text { Small town } / \mathrm{Ru}- \\
\text { ral-only Model } \\
(\# 8)\end{array}$} & \multicolumn{2}{|c|}{$\begin{array}{c}\text { Final Pooled } \\
\text { Model } \\
(\# 9)\end{array}$} \\
\hline & Coef. & Sig. & Coef. & Sig. & Coef. & Sig. & Coef. & Sig. & Coef. & Sig. \\
\hline $\begin{array}{l}\text { Number of days commut- } \\
\text { ing per week }\end{array}$ & 0.08 & 0.09 & $\begin{array}{r}0.09 \\
(-0.13)\end{array}$ & 0.30 & $\begin{array}{r}0.08 \\
(0.04)\end{array}$ & 0.22 & $\begin{array}{r}0.06 \\
(0.11)\end{array}$ & 0.72 & 0.07 & 0.12 \\
\hline Drove a car last week & -0.42 & 0.10 & $\begin{array}{r}-0.33 \\
(-0.19)\end{array}$ & 0.39 & $\begin{array}{r}-0.27 \\
(-0.33)\end{array}$ & 0.51 & $\begin{array}{r}-1.04 \\
(0.65)\end{array}$ & 0.26 & -0.35 & 0.19 \\
\hline Got a ride last week & 0.57 & 0.00 & $\begin{array}{r}\mathbf{0 . 8 1} \\
(-0.62)\end{array}$ & 0.02 & $\begin{array}{r}0.34 \\
(0.76)\end{array}$ & 0.17 & $\begin{array}{r}1.11 \\
(-0.82)\end{array}$ & 0.08 & 0.57 & 0.00 \\
\hline Got a ride last month & 0.46 & 0.01 & $\begin{array}{r}\mathbf{0 . 8 4} \\
(-1.08)\end{array}$ & 0.01 & $\begin{array}{r}0.28 \\
(0.61)\end{array}$ & 0.20 & $\begin{array}{r}0.47 \\
(-0.03)\end{array}$ & 0.41 & 0.47 & 0.01 \\
\hline Has a disability & 0.56 & 0.12 & $\begin{array}{r}0.57 \\
(-0.02)\end{array}$ & 0.34 & $\begin{array}{r}0.44 \\
(0.18)\end{array}$ & 0.42 & $\begin{array}{r}0.48 \\
(0.07)\end{array}$ & 0.63 & 0.56 & 0.13 \\
\hline $\begin{array}{l}\text { Has physical health } \\
\text { concerns that interfere with } \\
\text { ability to carry out daily } \\
\text { activities }\end{array}$ & 0.68 & 0.13 & $\begin{array}{r}0.43 \\
(0.27)\end{array}$ & 0.60 & $\begin{array}{r}0.72 \\
(-0.06)\end{array}$ & 0.23 & $\begin{array}{r}1.11 \\
(-0.31)\end{array}$ & 0.41 & 0.65 & 0.15 \\
\hline Female (ref. male) & 0.32 & 0.02 & $\begin{array}{r}-0.32 \\
(\mathbf{2 . 1 1})\end{array}$ & 0.23 & $\begin{array}{r}\mathbf{0 . 4 0} \\
(-0.37)\end{array}$ & 0.03 & $\begin{array}{r}1.76 \\
(-2.82)\end{array}$ & 0.00 & 0.43 & 0.02 \\
\hline $\begin{array}{l}\text { Older Adult (ref. 55-64 } \\
\text { years) }\end{array}$ & -0.10 & 0.51 & $\begin{array}{r}0.14 \\
(-0.73)\end{array}$ & 0.63 & $\begin{array}{r}-0.22 \\
(0.45)\end{array}$ & 0.29 & $\begin{array}{r}0.20 \\
(-0.53)\end{array}$ & 0.72 & -0.09 & 0.59 \\
\hline White (ref. other race/s) & -0.07 & 0.64 & $\begin{array}{r}-0.05 \\
(-0.04)\end{array}$ & 0.85 & $\begin{array}{r}-0.07 \\
(0.03)\end{array}$ & 0.70 & $\begin{array}{r}0.34 \\
(-0.82)\end{array}$ & 0.48 & -0.03 & 0.86 \\
\hline Hispanic & 0.25 & 0.20 & $\begin{array}{r}0.17 \\
(0.21)\end{array}$ & 0.64 & $\begin{array}{r}0.39 \\
(-0.42)\end{array}$ & 0.14 & $\begin{array}{r}-0.28 \\
(0.85)\end{array}$ & 0.64 & 0.24 & 0.23 \\
\hline Has a college degree & -0.08 & 0.60 & $\begin{array}{r}0.17 \\
(-0.74)\end{array}$ & 0.58 & $\begin{array}{r}-0.17 \\
(0.33)\end{array}$ & 0.41 & $\begin{array}{r}-0.75 \\
(1.10)\end{array}$ & 0.20 & -0.12 & 0.44 \\
\hline $\begin{array}{l}\text { Pre-tax annual household } \\
\text { Income in } 2018(\$ 10,000)\end{array}$ & -0.02 & 0.02 & $\begin{array}{l}\mathbf{- 0 . 0 4} \\
(0.81)\end{array}$ & 0.04 & $\begin{array}{r}\mathbf{- 0 . 0 3} \\
(0.26)\end{array}$ & 0.03 & $\begin{array}{r}0.07 \\
(-2.57)\end{array}$ & 0.04 & -0.03 & 0.00 \\
\hline Urban & & & & & & & & & 0.74 & 0.00 \\
\hline Small town/Rural & & & & & & & & & -1.61 & 0.00 \\
\hline Urban $\times$ Female & & & & & & & & & -0.76 & 0.02 \\
\hline Small town/Rural $\times$ Female & & & & & & & & & 1.15 & 0.02 \\
\hline $\begin{array}{l}\text { Small town/Rural } \times \text { Pre-tax } \\
\text { annual household Income } \\
\text { in } 2018(\$ 10,000)\end{array}$ & & & & & & & & & 0.03 & 0.01 \\
\hline (Intercept) & 0.46 & 0.20 & $\begin{array}{r}0.68 \\
(-0.30) \\
\end{array}$ & 0.28 & $\begin{array}{r}0.48 \\
(-0.02) \\
\end{array}$ & 0.36 & $\begin{array}{r}-0.83 \\
(1.01)\end{array}$ & 0.50 & 0.35 & 0.37 \\
\hline \multicolumn{11}{|l|}{ Model Statistics } \\
\hline Obs. & 987 & & 311 & & 561 & & 113 & & 987 & \\
\hline McFadden's $\rho 2$ & 0.68 & & 0.65 & & 0.69 & & 0.80 & & 0.68 & \\
\hline AIC & 1255.63 & & 1242.30 & & 740.39 & & 152.86 & & 1242.30 & \\
\hline LL(MS) & -1934.68 & & -511.06 & & -1086.33 & & -325.71 & & -1934.87 & \\
\hline $\operatorname{LL}(\rho)$ & -613.81 & & -176.92 & & -357.19 & & -63.43 & & -603.17 & \\
\hline $\begin{array}{l}\text { Chi-sq test (significant at } \\
0.005 \text { ) }\end{array}$ & -11.26 & & & & & & & & & \\
\hline
\end{tabular}

Notes: (1) Binary logit pooled and segmented models presented; (2) Bolded values are significant at 90\%; (3) Numbers in brackets below the parameter estimates indicate the t-test values for significance of differences in parameter estimates between the initial model and that particular model (urban, suburb, or small town/rural) calculated as per Koppelman and Bhat (2006). 
For the outcome variable "I don't have to worry about getting lost driving myself," the only coefficient significantly different between the initial pooled (\#10) model and segmented models is being female in the urban (\#11) model. Therefore, while estimating the final pooled (\#14) model, the interaction term of (urban $\times$ female) was introduced and retained because it was significant.

Table 5. Not getting lost while driving: A reason for adopting ride-hailing?

\begin{tabular}{|c|c|c|c|c|c|c|c|c|c|c|}
\hline & \multicolumn{2}{|c|}{$\begin{array}{c}\text { Initial Pooled } \\
\text { Model } \\
(\# 10) \\
\end{array}$} & \multicolumn{2}{|c|}{$\begin{array}{c}\text { Urban-only } \\
\text { Model } \\
(\# 11)\end{array}$} & \multicolumn{2}{|c|}{$\begin{array}{l}\text { Suburb-only } \\
\text { Model } \\
(\# 12)\end{array}$} & \multicolumn{2}{|c|}{$\begin{array}{c}\text { Small town } / \mathrm{Ru}- \\
\text { ral-only Model } \\
(\# 13)\end{array}$} & \multicolumn{2}{|c|}{$\begin{array}{c}\text { Final Pooled } \\
\text { Model } \\
(\# 14)\end{array}$} \\
\hline & Coef. & Sig. & Coef. & Sig. & Coef. & Sig. & Coef. & Sig. & Coef. & Sig. \\
\hline $\begin{array}{l}\text { Number of days commut- } \\
\text { ing per week }\end{array}$ & 0.01 & 0.91 & $\begin{array}{r}0.09 \\
(-0.90)\end{array}$ & 0.28 & $\begin{array}{r}-0.02 \\
(0.31)\end{array}$ & 0.76 & $\begin{array}{r}-0.12 \\
(0.76)\end{array}$ & 0.45 & 0.00 & 0.93 \\
\hline Drove a car last week & -0.31 & 0.21 & $\begin{array}{r}-0.26 \\
(-0.11)\end{array}$ & 0.48 & $\begin{array}{r}-0.16 \\
(-0.31)\end{array}$ & 0.68 & $\begin{array}{l}-0.70 \\
(0.43)\end{array}$ & 0.43 & -0.27 & 0.29 \\
\hline Got a ride in last week & 0.57 & 0.00 & $\begin{array}{r}\mathbf{0 . 8 5} \\
(-0.75)\end{array}$ & 0.01 & $\begin{array}{r}0.35 \\
(0.71)\end{array}$ & 0.15 & $\begin{array}{r}0.72 \\
(-0.25)\end{array}$ & 0.21 & 0.55 & 0.00 \\
\hline Got a ride last month & 0.54 & 0.00 & $\begin{array}{r}\mathbf{0 . 8 0} \\
(-0.73)\end{array}$ & 0.01 & $\begin{array}{r}\mathbf{0 . 4 2} \\
(0.43)\end{array}$ & 0.06 & $\begin{array}{r}0.51 \\
(0.06)\end{array}$ & 0.35 & 0.55 & 0.00 \\
\hline Has a disability & 0.56 & 0.11 & $\begin{array}{r}0.60 \\
(-0.06)\end{array}$ & 0.28 & $\begin{array}{r}0.58 \\
(-0.03)\end{array}$ & 0.29 & $\begin{array}{r}1.17 \\
(-0.65)\end{array}$ & 0.19 & 0.59 & 0.10 \\
\hline $\begin{array}{l}\text { Has physical health con- } \\
\text { cerns that interfere with } \\
\text { ability to carry out daily } \\
\text { activities }\end{array}$ & 0.44 & 0.29 & $\begin{array}{l}-0.39 \\
(1.07)\end{array}$ & 0.55 & $\begin{array}{r}0.47 \\
(-0.05)\end{array}$ & 0.41 & $\begin{array}{r}0.00 \\
(-1.06)\end{array}$ & & 0.40 & 0.34 \\
\hline Female (ref. male) & 0.37 & 0.01 & $\begin{array}{r}-0.37 \\
(2.53)\end{array}$ & 0.16 & $\begin{array}{r}\mathbf{0 . 6 3} \\
(-1.12)\end{array}$ & 0.00 & $\begin{array}{r}1.00 \\
(-1.35)\end{array}$ & 0.02 & 0.70 & 0.00 \\
\hline $\begin{array}{l}\text { Older adult (ref. 55-64 } \\
\text { years) }\end{array}$ & -0.22 & 0.15 & $\begin{array}{r}0.02 \\
(-0.75)\end{array}$ & 0.94 & $\begin{array}{l}-0.32 \\
(0.37)\end{array}$ & 0.12 & $\begin{array}{r}-0.11 \\
(-0.23)\end{array}$ & 0.83 & -0.18 & 0.25 \\
\hline White (ref. other race/s) & -0.09 & 0.53 & $\begin{array}{r}0.07 \\
(-0.52)\end{array}$ & 0.79 & $\begin{array}{r}-0.04 \\
(-0.23)\end{array}$ & 0.85 & $\begin{array}{r}-0.51 \\
(0.90)\end{array}$ & 0.25 & -0.07 & 0.64 \\
\hline Hispanic & 0.24 & 0.22 & $\begin{array}{r}0.31 \\
(-0.19)\end{array}$ & 0.38 & $\begin{array}{r}0.40 \\
(-0.52)\end{array}$ & 0.12 & $\begin{array}{r}-0.61 \\
(1.41)\end{array}$ & 0.28 & 0.25 & 0.20 \\
\hline Has a college degree & 0.04 & 0.81 & $\begin{array}{r}0.27 \\
(-0.70)\end{array}$ & 0.36 & $\begin{array}{l}-0.08 \\
(0.47)\end{array}$ & 0.69 & $\begin{array}{r}-0.28 \\
(0.58)\end{array}$ & 0.60 & 0.01 & 0.96 \\
\hline $\begin{array}{l}\text { Pre-tax annual household } \\
\text { Income in } 2018(\$ 10,000)\end{array}$ & -0.02 & 0.02 & $\begin{array}{r}\mathbf{- 0 . 0 3} \\
(0.41)\end{array}$ & 0.10 & $\begin{array}{r}\mathbf{- 0 . 0 2} \\
(0.12)\end{array}$ & 0.06 & $\begin{array}{r}0.02 \\
(-1.33)\end{array}$ & 0.49 & -0.02 & 0.04 \\
\hline Urban & & & & & & & & & 0.89 & 0.00 \\
\hline Urban $\times$ Female & & & & & & & & & -1.09 & 0.00 \\
\hline (Intercept) & 0.47 & 0.18 & $\begin{array}{r}0.34 \\
(0.20) \\
\end{array}$ & 0.58 & $\begin{array}{r}0.42 \\
(0.09) \\
\end{array}$ & 0.42 & $\begin{array}{r}0.83 \\
(-0.29) \\
\end{array}$ & 0.47 & 0.14 & 0.71 \\
\hline \multicolumn{11}{|l|}{ Model Statistics } \\
\hline Obs. & 990 & & 311 & & 563 & & 115 & & 990 & \\
\hline McFadden's $\rho 2$ & 0.68 & & 0.65 & & 0.69 & & 0.78 & & 0.69 & \\
\hline AIC & 1283.20 & & 394.82 & & 744.08 & & 164.11 & & 1268.80 & \\
\hline LL(MS) & 1966.97 & & -525.79 & & -1086.33 & & -329.38 & & -1966.66 & \\
\hline $\operatorname{LL}(\rho)$ & -628.62 & & -184.41 & & -357.19 & & -70.06 & & -619.39 & \\
\hline $\begin{array}{l}\text { Chi-sq test (significant at } \\
0.005)\end{array}$ & -15.46 & & & & & & & & & \\
\hline
\end{tabular}

Notes: (1) Binary logit pooled and segmented models presented; (2) Bolded values are significant at 90\%; (3) Numbers in brackets below the parameter estimates indicate the $\mathrm{t}$-test values for significance of differences in parameter estimates between the initial model and that particular model (urban, suburb, or small town/rural) calculated as per Koppelman and Bhat (2006). 
For the outcome variable "I have help carrying heavy bags to my door," the coefficient of being female was significantly different between the initial pooled (\#15) and segmented urban (\#16) models. Therefore, an interaction term was introduced in the final pooled (\#19) models (urban $\times$ female). The interaction estimate is significant and was hence retained in the final pooled model.

Table 6. Getting help with carrying heavy bags: A reason for adopting ride-hailing?

\begin{tabular}{|c|c|c|c|c|c|c|c|c|c|c|}
\hline & \multicolumn{2}{|c|}{$\begin{array}{l}\text { Initial Pooled } \\
\text { Model } \\
(\# 15) \\
\end{array}$} & \multicolumn{2}{|c|}{$\begin{array}{c}\text { Urban-only } \\
\text { Model } \\
(\# 16) \\
\end{array}$} & \multicolumn{2}{|c|}{$\begin{array}{c}\text { Suburb-only } \\
\text { Model } \\
(\# 17)\end{array}$} & \multicolumn{2}{|c|}{$\begin{array}{c}\text { Small town } / \mathrm{Ru}- \\
\text { ral-only Model } \\
(\# 18)\end{array}$} & \multicolumn{2}{|c|}{$\begin{array}{c}\text { Final Pooled } \\
\text { Model } \\
(\# 19)\end{array}$} \\
\hline & Coef. & Sig. & Coef. & Sig. & Coef. & Sig. & Coef. & Sig. & Coef. & Sig. \\
\hline $\begin{array}{l}\text { Number of days commut- } \\
\text { ing per week }\end{array}$ & 0.05 & 0.29 & $\begin{array}{r}0.12 \\
(-0.74)\end{array}$ & 0.15 & $\begin{array}{r}0.02 \\
(0.26)\end{array}$ & 0.70 & $\begin{array}{r}0.06 \\
(-0.04)\end{array}$ & 0.72 & 0.05 & 0.29 \\
\hline Drove a car last week & -0.51 & 0.04 & $\begin{array}{r}-0.44 \\
(-0.18)\end{array}$ & 0.22 & $\begin{array}{l}-0.54 \\
(0.07)\end{array}$ & 0.17 & $\begin{array}{r}-0.01 \\
(-0.56)\end{array}$ & 0.99 & -0.46 & 0.07 \\
\hline Got a ride in last week & 0.42 & 0.02 & $\begin{array}{r}0.35 \\
(0.21)\end{array}$ & 0.28 & $\begin{array}{r}0.34 \\
(0.23)\end{array}$ & 0.18 & $\begin{array}{r}1.26 \\
(-1.21)\end{array}$ & 0.06 & 0.41 & 0.03 \\
\hline Got a ride last month & 0.44 & 0.01 & $\begin{array}{r}0.27 \\
(0.47)\end{array}$ & 0.36 & $\begin{array}{r}\mathbf{0 . 4 9} \\
(-0.15)\end{array}$ & 0.03 & $\begin{array}{r}0.84 \\
(-0.61)\end{array}$ & 0.19 & 0.45 & 0.01 \\
\hline Has a disability & 1.00 & 0.01 & $\begin{array}{r}1.47 \\
(-0.63)\end{array}$ & 0.02 & $\begin{array}{r}0.70 \\
(0.39)\end{array}$ & 0.18 & $\begin{array}{r}2.05 \\
(-1.06)\end{array}$ & 0.03 & 1.00 & 0.01 \\
\hline $\begin{array}{l}\text { Has physical health } \\
\text { concerns that interfere with } \\
\text { ability to carry out daily } \\
\text { activities }\end{array}$ & 1.03 & 0.02 & $\begin{array}{r}1.01 \\
(0.02)\end{array}$ & 0.22 & $\begin{array}{r}0.69 \\
(0.37)\end{array}$ & 0.20 & & & 1.02 & 0.02 \\
\hline Female (ref. male) & 0.75 & 0.00 & $\begin{array}{r}0.19 \\
(\mathbf{1 . 9 6 )}\end{array}$ & 0.45 & $\begin{array}{r}\mathbf{0 . 9 3} \\
(-0.65)\end{array}$ & 0.00 & $\begin{array}{r}1.58 \\
(-1.69)\end{array}$ & 0.00 & 1.02 & 0.00 \\
\hline $\begin{array}{l}\text { Older adult (ref. 55-64 } \\
\text { years) }\end{array}$ & -0.01 & 0.96 & $\begin{array}{r}0.23 \\
(-0.75)\end{array}$ & 0.41 & $\begin{array}{l}-0.10 \\
(0.29)\end{array}$ & 0.63 & $\begin{array}{r}0.11 \\
(-0.22)\end{array}$ & 0.83 & 0.04 & 0.81 \\
\hline White (ref. other race/s) & -0.01 & 0.94 & $\begin{array}{r}-0.06 \\
(0.15)\end{array}$ & 0.84 & $\begin{array}{r}0.04 \\
(-0.18)\end{array}$ & 0.82 & $\begin{array}{r}0.02 \\
(-0.06)\end{array}$ & 0.97 & 0.01 & 0.95 \\
\hline Hispanic & -0.24 & 0.20 & $\begin{array}{r}-0.20 \\
(-0.11)\end{array}$ & 0.55 & $\begin{array}{r}-0.09 \\
(-0.39)\end{array}$ & 0.71 & $\begin{array}{l}-1.28 \\
(1.58)\end{array}$ & 0.04 & -0.24 & 0.20 \\
\hline Has a college degree & -0.19 & 0.22 & $\begin{array}{r}0.04 \\
(-0.72)\end{array}$ & 0.88 & $\begin{array}{l}-0.32 \\
(0.39)\end{array}$ & 0.12 & $\begin{array}{l}-0.44 \\
(0.44)\end{array}$ & 0.42 & -0.22 & 0.15 \\
\hline $\begin{array}{l}\text { Pre-tax annual household } \\
\text { Income in } 2018(\$ 10,000)\end{array}$ & -0.03 & 0.01 & $\begin{array}{l}\mathbf{- 0 . 0 4} \\
(0.66)\end{array}$ & 0.03 & $\begin{array}{r}-0.02 \\
(-0.44)\end{array}$ & 0.19 & $\begin{array}{r}-0.03 \\
(0.17)\end{array}$ & 0.34 & -0.02 & 0.02 \\
\hline Urban & & & & & & & & & 0.78 & 0.00 \\
\hline Urban $\times$ Female & & & & & & & & & -0.86 & 0.00 \\
\hline (Intercept) & 0.07 & 0.85 & $\begin{array}{r}0.25 \\
(-0.27) \\
\end{array}$ & 0.67 & $\begin{array}{l}-0.01 \\
(0.12) \\
\end{array}$ & 0.98 & $\begin{array}{r}-1.32 \\
(1.13) \\
\end{array}$ & 0.26 & -0.27 & 0.47 \\
\hline \multicolumn{11}{|l|}{ Model Statistics } \\
\hline Obs. & 983 & & 309 & & 559 & & 114 & & 983 & \\
\hline McFadden's $\rho 2$ & 0.68 & & 0.65 & & 0.68 & & 0.81 & & 0.69 & \\
\hline AIC & 1289.50 & & 418.23 & & 744.40 & & 152.35 & & 1289.60 & \\
\hline LL(MS) & -2000.62 & & -542.70 & & -1110.01 & & -334.04 & & -2000.62 & \\
\hline $\operatorname{LL}(\rho)$ & -631.77 & & -196.11 & & -359.20 & & -64.18 & & -624.78 & \\
\hline $\begin{array}{l}\text { Chi-sq test (significant at } \\
0.005)\end{array}$ & -10.58 & & & & & & & & & \\
\hline
\end{tabular}

Notes: (1) Binary logit pooled and segmented models presented; (2) Bolded values are significant at 90\%; (3) Numbers in brackets below the parameter estimates indicate the $\mathrm{t}$-test values for significance of differences in parameter estimates between the initial model and that particular model (urban, suburb, or small town/rural) calculated as per Koppelman and Bhat (2006). 
The $\chi 2$ test of significance for model fit (Table 4) is $-2[\operatorname{LL}(\# 9)-\operatorname{LL}(\# 6)-\operatorname{LL}(\# 7)-\operatorname{LL}(\# 8)] \approx 11.26_{21}$ for "not having to rely on family and friends," and has a corresponding $\mathrm{p}$-value $<0.005$. Therefore, the null hypothesis that the pooled model is equivalent to the segmented models can be rejected at a significance level of 0.005 . We, therefore, choose the location-segmented models as better representations of the sample. Using the same reasoning for "not getting lost" (Table 5) -2[LL(\#14)-LL(\#11)-LL(\#12)$\mathrm{LL}(\# 13)] \approx 15.46_{23}$ which has a corresponding p-value $<0.005$. Therefore, the location-segmented models are better representation for this statement as well. Finally, "help with carrying bags" (Table 6), $-2[\mathrm{LL}(\# 19)-\mathrm{LL}(\# 16)-\mathrm{LL}(\# 17)-\mathrm{LL}(\# 18)] \approx 10.58_{23}$ also has a corresponding $\mathrm{p}$-value $<0.0005$. Therefore, for all the three statements, location-segmented models are better representation of the sample than pooled models. Overall, our modeling shows that there is significant variability by location in attitudes towards use of ride-hailing services among individuals 55 years and over in California, even when they share similar socio-demographic attributes.

\section{$7 \quad$ Summary of findings}

This section turns to assessing whether or not the findings confirm the four study hypotheses about which types of Californians 55 and older, denoted here as respondents, would agree with the four proposed reasons to ride-hail.

Hypothesis 1 - Socio-Demographics: We found that reasons to adopt ride-hailing were distinctly different across various socio-economic segments and by location type. The segmented models showed that suburban and small town/rural women were more likely than men to find three of the factors presented reasons to adopt ride-hailing; these were non-reliance on others, not getting lost, and help with carrying bags. However, urban females were less likely to find non-reliance on others and not getting lost as reasons to ride-hail as compared to their male counterparts. Women over 64 years from small town/ rural locations were open to adopting ride-hailing because they did not want to rely on others for rides.

Respondents from high-income households in small town/rural locations were more likely than respondents from low-income households to adopt ride-hailing for reasons of non-reliance on others and to avoid getting lost while driving. In contrast, their urban and suburban counterparts from highincome households were consistently less likely to adopt ride-hailing for any of the provided reasons as compared to respondents from low-income urban/suburban households. Older respondents in small town/rural locations were more likely to adopt ride-hailing than their younger counterparts to become self-reliant, and to get help in carrying heavy bags, which was similar to the preferences of older respondents in urban settings as well.

Socio-economic factors including age, race, ethnicity, and college education were included in the models to correct for sampling bias. The models show that these factors largely did not influence respondents' attitudes toward the importance of the three reasons for ride-hailing adoption.

Hypothesis 2 - Independence: We discovered that older adults who were dependent on others for rides were more likely to find one or more of the reasons significantly important for adopting ridehailing. Non-reliance on others for rides was an important reason for adopting ride-hailing in urban and small town/rural locations.

Additionally, based on findings from the initial pooled model, not getting lost was a significant reason for ride-hail acceptance in urban and suburban settings, while getting help with carrying bags encouraged respondents to ride-hail in suburban and small town/rural locations. Those who drove a car in the preceding week were significantly less likely to find help with carrying bags to be a reason to ridehail, which is likely a reflection of their independence. 
Hypothesis 3 - Health/Ability: We confirmed that disability status and the presence of physical health issues encouraged individuals to accept ride-hailing. The segmented models indicated that getting help with carrying bags was strongly associated with adoption of ride-hailing among urban and small town/rural respondents with disabilities.

Hypothesis 4 - Location/Community Type: Location/Community type mattered across the first three hypotheses as expected. Across the sample, respondents from urban centers found all three reasons important to adopt ride-hailing. Aging women in cities, however, were significantly less inclined to ridehail for the same reasons. Respondents from small towns or rural locations were less likely to ride-hail due to reasons of independence but women in these locations were more likely to adopt ride-hailing.

\section{$8 \quad$ Discussion and policy implications}

We explored the behavior and preferences of older age groups for ride-hailing across different geographical settings in California. The results of the study provide a basis for understanding how choices made, and reasons for adopting ride-hailing, can differ between individuals from urban, suburban, and small town/rural areas.

The results from the segmented models indicate that relying on others for rides, coming from an urban low-income or a small town/rural high-income household, and being female all relate to increasing the likelihood of adopting ride-hailing for reasons including independence, not getting lost, and help with carrying bags. In contrast to findings in earlier research about millennial and generation $\mathrm{X}$ ride-hailing adoption by Alemi et al. (2018), our research shows that lower income makes it more likely that an urban Californian who is 55 or older will ride-hail. Our study, however, corroborates the landuse related findings in Alemi et al. (2018). The home location difference is significant enough to warrant modeling separately the choices of reasons given by participants from urban, suburban, and small town/ rural geographies. We show that the geographical differences are significant enough that people residing in these different areas should be considered separately when evaluating policies for ride-hailing services.

Urban women consistently do not find non-reliance or getting lost while driving as reasons to adopt ride-hailing in contrast to the findings related to their suburban or small town/rural counterparts. It is likely that urban residents have more mobility choices than their non-urban counterparts. Urban travel options like public transit also reduce the prospect of getting lost. This finding corroborates Payyanadan and Lee (2018) in that rural and suburban seniors are more reliant on others for getting rides, while urban seniors are generally less reliant on others since they have other travel options such as public transit and taxis. Hence, for suburban and non-urban seniors, it might be helpful to introduce microtransit options, and/or to encourage private supply through for-profit companies or faith-based groups. In urban locations, coordination between public transit and ride-hailing services (Leistner \& Steiner, 2017) to help make the first- and last-mile connection easy has the potential to extend transit travel options for older adults.

One of the attractions of ride-hailing was having help with carrying bags across all location types. A market incentive, such as a reasonable surcharge for ride-hail operators to help older adults with moving bags, is indicated. Such a feature could especially prove helpful for those with disabilities. Further research is needed to explore such an option.

Our models indicated that those who rely on others for rides or do not drive are more likely to accept ride-hailing as a travel option. Policies that suggest ride-hailing as a travel option during regular medical checkups or license renewal may help to introduce Lyft/Uber to older adults.

As the relatively younger cohort ages, their comfort with ride-hailing and reasons for using such services may increase ride-hailing demand. While ride-hailing has the potential to promote healthy ag- 
ing by expanding travel choices, there is also a need for sufficient availability of ride-hailing services in suburban and small town/rural areas to meet the mobility needs of older adults aging in place. A study of ride-hailing service in San Francisco (San Francisco County Transportation Authority, 2018) indicated that the service responds to consistent demand in already congested areas rather than areas that are not well served by other modes and where there is inconsistent or sparse demand (Hughes \& MacKenzie, 2016; Yu \& Peng, 2019). Thus, supplying ride-hailing services in suburban and small town/rural locations may need to be incentivized or regulated.

As with most surveys, one key limitation of the data was that the sample was not entirely representative of the population, even though the quota sampling method ensured that the sample was reasonably representative of California's socio-demographic groups in terms of age, gender, income, education, race, and ethnicity. Specifically, 14\% of California’s population over the age of 55 does not have internet access and is not included in this study. It is likely that our findings understate the potential for ridehailing adoption in these groups. Future research efforts, such as exploring the use of mobility managers who work with communities to help older adults without internet gain access to ride-hailing services, can overcome this limitation.

\section{Acknowledgements}

We thank Giovanni Circella, Cameron Simons, and the team at Qualtrics for insights and support on this project.

\section{Funding}

This research was funded through grant\# 69A3551747127 by the Mineta Transportation Institute at the San José State University, California. Project details are available at https://scholarworks.sjsu.edu/ mti_publications/325/ 


\section{References}

Agrawal, A. W., Shirgaokar, M., Misra, A., Wachs, M., \& Dobbs, B. (2020). Will ride-hailing enhance mobility for older adults? A California survey (No. 20-30; p. 79). San Jose, CA: Mineta Transportation Institute. https://doi.org/10.31979/mti.2020.1815

Alemi, F., Circella, G., Handy, S., \& Mokhtarian, P. (2018). What influences travelers to use Uber? Exploring the factors affecting the adoption of on-demand ride services in California. Travel Behavior and Society, 13, 88-104. https://doi.org/10.1016/j.tbs.2018.06.002

Alemi, F., Circella, G., Mokhtarian, P., \& Handy, S. (2019). What drives the use of ridehailing in California? Ordered probit models of the usage frequency of Uber and Lyft. Transportation Research Part C: Emerging Technologies, 102, 233-248. https://doi.org/10.1016/j.trc.2018.12.016

Ben-Akiva, M., Mcfadden, D., Train, K., Walker, J., Bhat, C., Bierlaire, M., ... \& Munizaga, M. A. (2002). Hybrid choice models: Progress and challenges. Marketing Letters, 13(3), 163-175. https:// doi.org/10.1023/A:1020254301302

Brown, A. (2019a). Redefining car access: Ride-hail travel and use in Los Angeles. Journal of the American Planning Association, 85(2), 83-95. https://doi.org/10.1080/01944363.2019.1603761

Brown, A. (2019b). Prevalence and mechanisms of discrimination: Evidence from the ride-hail and taxi industries. Journal of Planning Education and Research. https://doi.org/10.1177/0739456X19871687

California Dept. of Finance. (2020). Demographic projections (total estimated and projected population for California: July 1, 2010 to July 1, 2060 in 1-year increments). Retrieved from http://www. dof.ca.gov/Forecasting/Demographics/Projections/

Chen, Y., Bouferguene, A., Shirgaokar, M., \& Al-Hussein, M. (2020). Spatial analysis framework for age-restricted communities integrating spatial distribution and accessibility evaluation. Journal of Urban Planning and Development, 146(1). https://doi.org/10.1061/(ASCE)UP.1943-5444.0000537

Chihuri, S., Mielenz, T., DiMaggio, C., Betz, M., DiGuiseppi, C., Jones, V., \& Li, G. (2016). Driving cessation and health outcomes in older adults. Journal of the American Geriatrics Society, 64(2), 332-341. https://doi.org/10.1111/jgs.13931

Conway, M. W., Salon, D., \& King, D. A. (2018). Trends in taxi use and the advent of ride hailing, 1995-2017: Evidence from the US national household travel survey. Urban Science, 2(3), 79. https://doi.org/10.3390/urbansci2030079

Coughlin, J. F. (2009). Longevity, lifestyle, and anticipating the new demands of aging on the transportation system. Public Works Management \& Policy, 13(4), 301-311. https://doi. org/10.1177/1087724X09335609

Diller, E., Cook, L., Leonard, D., Reading, J., Dean, J., \& Vernon, D. (1999). Evaluating drivers licensed with medical conditions in Utah, 1992-1996 (NHTSA DOT HS 809 023). Washington, DC: US DOT. Retrieved from https://one.nhtsa.gov/people/injury/research/utahdrivers/utahmedconditions.html

Enam, A., Konduri, K., Eluru, N., \& Ravulaparthy, S. (2017). Relationship between well-being and daily time use of elderly: Evidence from the disabilities and use of time survey. Transportation, 45, 1783-1810. https://doi.org/10.1007/s11116-017-9821-z

Erhardt, G. D., Roy, S., Cooper, D., Sana, B., Chen, M., \& Castiglione, J. (2019). Do transportation network companies decrease or increase congestion? Science Advances, 5(5), 1-11. https://doi. org/10.1126/sciadv.aau 2670

Federal Highway Administration. (2018, November). Highway statistics 2017 (Table DL-20). Retrieved from https://www.fhwa.dot.gov/policyinformation/statistics/2017/dl20.cfm

Figueroa, M. J., Nielsen, T. A. S., \& Siren, A. (2014). Comparing urban form correlations of the travel 
patterns of older and younger adults. Transport Policy, 35, 10-20. https://doi.org/10.1016/j.tranpol.2014.05.007

Foley, D. J., Heimovitz, H. K., Guralnik, J. M., \& Brock, D. B. (2002). Driving life expectancy of persons aged 70 years and older in the United States. American Journal of Public Health, 92(8), $1284-1289$.

Frey, W. (2011). The uneven aging and "younging" of America: State and metropolitan trends in the 2010 Census (p. 21). Washington, DC: Brookings Institution. Retrieved from https://www.brookings. edu/wp-content/uploads/2016/06/0628_census_aging_frey.pdf

Gehrke, S. R., Felix, A., \& Reardon, T. G. (2019). Substitution of ride-hailing services for more sustainable travel options in the greater Boston region. Transportation Research Record: Journal of the Transportation Research Board, 2673(1), 438-446. https://doi.org/10.1177/0361198118821903

Grahn, R., Harper, C. D., Hendrickson, C., Qian, Z., \& Matthews, H. S. (2019). Socioeconomic and usage characteristics of transportation network company (TNC) riders. Transportation, 47, 30473067. https://doi.org/10.1007/s11116-019-09989-3

Haustein, S., \& Siren, A. (2015). Older people's mobility: Segments, factors, trends. Transport Reviews, 35(4), 466-487. https://doi.org/10.1080/01441647.2015.1017867

Henao, A., \& Marshall, W. E. (2018). The impact of ride-hailing on vehicle miles traveled. Transportation, 46, 2173-2194. https://doi.org/10.1007/s11116-018-9923-2

Hess, D., Norton, T., Park, J.-Y., \& Street, D. (2016). Driving decisions of older adults receiving meal delivery: The influence of individual characteristics, the built environment, and neighborhood familiarity. Transportation Research Part A: Policy and Practice, 88, 73-85. https://doi.org/10.1016/j. tra.2016.03.011

Hughes, R., \& MacKenzie, D. (2016). Transportation network company wait times in greater Seattle, and relationship to socioeconomic indicators. Journal of Transport Geography, 56, 36-44. https://doi. org/10.1016/j.jtrangeo.2016.08.014

Keenan, T. (2010). Home and community preferences of the 45+ population (p. 25). American Washington, DC: Association of Retired Persons. Retrieved from https:/assets.aarp.org/rgcenter/general/ home-community-services-10.pdf

Kim, S. (2011a). Assessing mobility in an aging society: Personal and built environment factors associated with older people's subjective transportation deficiency in the US. Transportation Research Part F: Traffic Psychology and Behavior, 14(5), 422-429. https://doi.org/10.1016/j.trf.2011.04.011

Kim, S. (2011b). Transportation alternatives of the elderly after driving cessation. Transportation Research Record: Journal of the Transportation Research Board, 2265, 170-176. https://doi.org/10.3141/226519

Kim, S., \& Ulfarsson, G. (2013). Transportation in an aging society: Linkage between transportation and quality of life. Transportation Research Record: Journal of the Transportation Research Board, 2357, 109-115. https://doi.org/10.3141/2357-13

Kim, S., \& Ulfarsson, G. (2015). Activity space of older and working-age adults in the Puget Sound region, Washington. Transportation Research Record: Journal of the Transportation Research Board, 2494, 37-44. https://doi.org/10.3141/2494-05

Koppelman, F., \& Bhat, C. (2006). A self-instructing course in mode choice modeling: Multinomial and nested logit models. Washington, DC: U.S. Department of Transportation. Retrieved from http:// www.caee.utexas.edu/prof/bhat/courses/lm_draft_060131final-060630.pdf

Leistner, D., \& Steiner, R. (2017). Uber for seniors? Exploring transportation options for the future. Transportation Research Record: Journal of the Transportation Research Board, 2660, 22-29. https://doi. org/10.3141/2660-04 
Li, M., \& Tilahun, N. (2017). Time use, disability, and mobility of older Americans. Transportation Research Record: Journal of the Transportation Research Board, 2650, 58-65. https://doi. org/10.3141/2650-07

Medina, L., Sabo, S., \& Vespa, J. (2020). Living longer: Historical and projected life expectancy in the United States, 1960 to 2060 (No. P25-1145; current population reports, p. 27). Washington, DC: US Census Bureau. Retrieved from https://www.census.gov/content/dam/Census/library/publications/2020/demo/p25-1145.pdf

Middleton, S., \& Zhao, J. (2019). Discriminatory attitudes between ridesharing passengers. Transportation, 47, 2391-2414. https://doi.org/10.1007/s11116-019-10020-y

Parker, K., Horowitz, J., Brown, A., Fry, R., Cohn, D., \& Igielnik, R. (2018, May 22). Demographic and economic trends in urban, suburban and rural communities (Pew Research Center social and demographic trends project). Washington, DC: Pew Research Center. Retrieved from https://www. pewsocialtrends.org/2018/05/22/demographic-and-economic-trends-in-urban-suburban-and-rural-communities/

Payyanadan, R. P., \& Lee, J. D. (2018). Understanding the ridesharing needs of older adults. Travel Behavior and Society, 13, 155-164. https://doi.org/10.1016/j.tbs.2018.08.002

Ravulaparthy, S., Konduri, K., \& Goulias, K. (2016). Fundamental linkages between activity time use and subjective well-being for the elderly population: Joint exploratory analysis framework for inhome and out-of-home activities. Transportation Research Record: Journal of the Transportation Research Board, 2566, 31-40. https://doi.org/10.3141/2566-04

Rosenbloom, S. (2011). Driving off into the sunset: The implications of the growing automobility of older travelers. In Auto motives: Understanding car use behaviors (pp. 173-192). Bingley, UK: Emerald Group Publishing Limited.

Rosenbloom, S. (2012). The travel and mobility needs of older people now and in the future. In $A g$ ing America and transportation: Personal choices and public policy (pp. 58-73). New York: Springer Publishing Company.

Rosenbloom, S., \& Herbel, S. (2009). The safety and mobility patterns of older women: Do current patterns foretell the future? Public Works Management \& Policy, 13(4), 338-353. https://doi. org/10.1177/1087724X09334496

Rosenbloom, S., \& Winsten-Bartlett, C. (2002). Asking the right question: Understanding the travel needs of older women who do not drive. Transportation Research Record: Journal of the Transportation Research Board, 1818, 78-82. https://doi.org/10.3141/1818-12

San Francisco County Transportation Authority, (SFCTA). (2018). TNCs \& congestion (p. 35). Retrieved from https://www.sfcta.org/sites/default/files/2019-05/TNCs_Congestion_Report_181015_Finals.pdf

Shirgaokar, M. (2018). Expanding seniors' mobility through phone apps: Potential responses from the private and public sectors. Journal of Planning Education and Research, 40(4), 405-415. https://doi. org/10.1177/0739456X18769133

Shirgaokar, M., Dobbs, B., Anderson, L., \& Hussey, E. (2020). Do rural older adults take fewer trips than their urban counterparts for lack of a ride? Journal of Transport Geography, 87. https://doi. org/10.1016/j.jtrangeo.2020.102819

Sikder,S. (2019). Who uses ride-hailing services in the United States? Transportation Research Record:Journal of the Transportation Research Board, 2673(12), 40-54. https://doi.org/10.1177/0361198119859302

Siren, A., \& Haustein, S. (2013). Baby boomers' mobility patterns and preferences: What are the implications for future transport? Transport Policy, 29, 136-144. https://doi.org/10.1016/j.tranpol.2013.05.001

Su, F., \& Bell, M. G. H. (2012). Travel differences by gender for older people in London. Research in 
Transportation Economics, 34(1), 35-38. https://doi.org/10.1016/j.retrec.2011.12.011

Tirachini, A. (2019). Ride-hailing, travel behavior and sustainable mobility: An international review. Transportation, 47, 2011-2047. https://doi.org/10.1007/s11116-019-10070-2

US Census Bureau. (2018, March). 2017 national population projections tables. Retrieved from https:// www.census.gov/data/tables/2017/demo/popproj/2017-summary-tables.html

Vaa, T. (2003). Impairment, diseases, age and their relative risks of accident involvement: Results from metaanalysis (No. 690/2003; p. 58). Oslo: Institute of Transport Economics. Retrieved from https:// www.toi.no/getfile.php?mmfileid $=5780$

Vivoda, J. M., Harmon, A. C., Babulal, G. M., \& Zikmund-Fisher, B. J. (2018). E-hail (rideshare) knowledge, use, reliance, and future expectations among older adults. Transportation Research Part F: Traffic Psychology and Behavior, 55, 426-434. https://doi.org/10.1016/j.trf.2018.03.020

Yu, H., \& Peng, Z.-R. (2019). Exploring the spatial variation of ridesourcing demand and its relationship to built environment and socioeconomic factors with the geographically weighted Poisson regression. Journal of Transport Geography, 75, 147-163. https://doi.org/10.1016/j.jtrangeo.2019.01.004 